De Jure: Jurnal Hukum dan Syari'ah

Vol. 9, No. 2, 2017, h. 117-127

ISSN (Print): 2085-1618, ISSN (Online): 2528-1658

DOI: http://dx.doi.org/10.18860/j-fsh.v9i2.6991

Available online at http://ejournal.uin-malang.ac.id/index.php/syariah

\title{
Penyerapan Fiqh Madzhab Syafi’i dalam Penyusunan Kompilasi Hukum Islam
}

\author{
Khairul Umam \\ UIN Maulana Malik Ibrahim Malang, Indonesia \\ khaeroeloemam@gmail.com
}

Abstrak :

Islamic Law Compilation is still an interesting topic to study by Muslim scholars in Indonesia. The Islamic Law Compilation is a typical Indonesian jurisprudence used as reference for religious court judges. This article aims to identify the use of the Shafi'ite school on the rules of marriage in the Islamic Law Compilation. This article comes from normative research with a descriptive approach. The results of this study show that the influence of the Shafi'i school is more dominant in the Islamic Law Compilation. However, the compilers of the Islamic Law Compilations used the opinion of other schools. The articles relating to the requirements, pillars and procedures for implementing marriage are absorbed from the provisions of the Shafi'ite jurisprudence. Such as marital proposal, marriage guardian, ijab qabul, and dowry. the Islamic Law Compilation is not only collecting or adopting the classical jurisprudence of Islamic scholars, but it also provides a new provision that has not yet existed in the treasures of the previous Islamic jurisprudence.

Kompilasi Hukum Islam masih menjadi bahan menarik untuk dikaji oleh sarjana muslim di Indonesia. Kompilasi Hukum Islam merupakan fiqh khas Indonesia yang dijadikan rujukan bagi hakim pengadilan agama. Artikel ini bertujuan mengidentifikasi penggunaan mazhab Syafi'i pada aturan perkawinan dalam Kompilasi Hukum Islam. Artikel ini berasal dari penelitian normatif dengan pendekatan deskriptif. Hasil penelitian ini menujukkan bahwa Pengaruh mazhab Syafi'i lebih dominan dalam penyusunan Kompilasi Hukum Islam. Meskipun demikian, para perumus Kompilasi Hukum Islam menggunakan pendapat mazhab lain. Pasal-pasal yang berkaitan dengan syarat, rukun dan tata cara pelaksanaan perkawinan diserap dari ketentuan fiqh mazhab Syafi'i. Seperti peminangan, wali nikah, ijab qabul, mahar. Kompilasi Hukum Islam bukan hanya sekedar mengumpulkan atau mengadopsi pandagan ulama fiqh klasik. Akan tetapi memberikan ketentuan baru yang belum ada dalam khazanah fiqh terdahulu.

Kata Kunci: kompilasi hukum Islam; mazhab Syafi'i; pengadilan agama.

\section{Pendahuluan}

Fiqh berkembang secara dinamis sesuai dengan perkembangan zaman. Fondasi Fiqh diletakkan sejak masa Rasulullah Saw. dan dikembangkan oleh para sahabat. Pada abad ke-8 M. Para sarjana Islam memberikan perhatian yang besar dalam 
pengembangan Fiqh. Beberapa pakar yang memiliki peran penting dalam pengembangan Fiqh seperti Imam Abu Hanifah, Imam Malik bin Anas, Imam Muhammad bin Idris al-Syaf'i, dan Imam Ahmad ibn Hanbal. Perhatian para pakar ini kemudian memunculkan mazhab besar yang memiliki banyak pengikut di seluruh dunia. Fiqh pada awalnya berasal dari pemahaman seseorang terhadap nash karena ada problem di masyarakat. Pendapat ini kemudian diikuti oleh murid-murid dan dibakukan dalam metode tertentu. ${ }^{1}$

Fiqh kemudian menjadi salah satu rujukan umat Islam dalam menjalankan praktik ibadah dan muamalah. Selain itu, fiqh yang tersebar di berbagai kitab menjadi sumber rujukan dalam praktik peradilan Islam. ${ }^{2}$ Sebelum memberikan putusan, hakim wajib memberikan pertimbangan hukum sesuai dalil-dalil syara' yang bersumber dari AlQur'an, Sunnah, dan pandangan ulama fiqh. ${ }^{3}$ Menurut Alaidin Koto, fiqh -khususnya mazhab Syafi'i- telah dijadikan sumber hukum memutus perkara sejak kerajaankerajaan Islam di nusantara. ${ }^{4}$ Pada tahun 1958, Biro Peradilan Agama Departemen Agama mengeluarkan Surat Edaran Nomor B/1/1735, tanggal 18 Februari 1958 tentang beberapa kitab fiqh yang dapat dijadikan rujukan dalam menangani perkara, antara lain: al-Bajuri, Fatchul Mu'in, Syarqowi 'ala Tahrir, Qalyubi/Mahalli, Tuhfah, Targhibul Musytaq, Fathul Wahhab dan Syarahnya, Qawaninus Syari'ah Lis Sayyid bin Yahya, Qawaninus Syari'ah Li al-Sayyid Sadaqah Dahlan, Syamsuri fil Faraidh, Bugyatul Mustarsyidin, al-Fiqh 'ala Madzahib Arba'ah dan Mugnil Muhtaj. ${ }^{5}$

Meskipun sudah lama dipraktikkan, penggunaan fiqh dalam memberikan putusan di peradilan menyimpan masalah. Setiap hakim memiliki kebebasan merujuk kitab fiqh sebagai dasar hukum. Konsekuensinya, sering terjadi perbedaan pendapat dalam pengambilan keputusan. Selain itu, muncul disparitas putusan pengadilan dalam kasus yang sama. ${ }^{6}$ Kondisi ini bertahan hingga tahun 1990 -an. Sebagai langkah menangani problem di atas, pemerintah bekerjasama dengan berbagai instansi menyusun Kompilasi Hukum Islam, yang terdiri dari tiga buku. Buku pertama tentang hukum perkawinan. Buku kedua tentang hukum kewarisan. Buku ketiga tentang hukum perwakafan bagi umat Islam. ${ }^{7}$ Kompilasi Hukum Islam kemudian disebarluaskan melalui Instruksi Presiden RI Nomor 1 Tahun 1991. Melalui instruksi presiden ini, masyarakat umum dan instansi pemerintah yang menangani perkawinan, kewarisan, dan perwakafan diminta menggunakan Kompilasi Hukum Islam sebagai rujukan. ${ }^{8}$

Sejak disebarluaskan pada tahun 1991, Kompilasi Hukum Islam telah banyak dikaji. Abdul Hadi melakukan kajian dengan judul "Fikih Mazhab Syafi'i dalam Peraturan Perundang-Undangan tentang Perkawinan di Indonesia, Brunei, dan Malaysia (1971-1991)". Hasil penelitian ini menunjukkan bahwa hukum perkawinan di Indonesia

${ }^{1}$ Nafiul Lubab and Novita Pancaningrum, "Mazhab: Keterkungkungan Intelektual Atau Kerangka Metodologis (Dinamika Hukum Islam)," YUDISIA : Jurnal Pemikiran Hukum Dan Hukum Islam 6, no. 2 (December 1, 2015): 402-403, https://doi.org/10.21043/yudisia.v6i2.1462.

2 Ahmad Mujahidin, Pembaruan Hukum Acara Perdata Peradilan Agama Dan Mahkamah Syari'ah Di Indonesia (Jakarta: IKAHI, 2008), 41.

3 Abdul Manan, Penerapan Hukum Acara Perdata Di Lingkungan Peradilan Agama (Jakarta: Kencana, 2010), 200.

${ }^{4}$ Alaidin Koto, Sejarah Peradilan Islam (Jakarta: RajaGrafindo Persada, 2011), 192.

${ }^{5}$ Mujahidin, Pembaharuan Hukum Acara, 200.

6 Muhammad Gazali Rahman, "Kompilasi Hukum Islam Sebagai Hukum Terapan Bagi Hakim Pengadilan Agama," Tahkim 11, no. 2 (2015): 78.

${ }^{7}$ Rahman, 80 .

${ }^{8}$ Instruksi Presiden RI Nomor 1 Tahun 1991 tentang Penyebarluasan Kompilasi Hukum Islam 
sebagian besar dipengaruhi oleh mazhab Syafi'i. Ketentuan yang banyak mengikuti pandangan mazhab Syafi'i berkaitan syarat dan rukun perkawinan baik disusun secara sistematis maupun terpapar dalam pasal-pasal. Sebagaimana terdapat dalam rumusan Kompilasi Hukum Islam. ${ }^{9}$ Penelitian Nurjihad dengan judul "Pembaharuan Hukum Islam di Indonesia Studi Kasus CLD Kompilasi Hukum Islam". Hasil penelitian ini menunjukkan bahwa pembaharuan hukum Islam perlu dilakukan untuk kemaslahatan umat dengan tetap memperhatikan tujuan pemberlakuan hukum Islam. Ijtihad harus dilakukan oleh banyak orang yang memiliki bidang keahlian yang berbeda. Munculnya Kompilasi Hukum Islam membuka ruang dinamika pengembangan fiqh di Indonesia. Salah satunya dengan kemunculan Counter Legal Draf Kompilasi Hukum Islam. Meskipun dalam perkembangannya CLD KHI ini ditarik dari peredaran. ${ }^{10}$

Yulkarnain Harahab dan Andy Omara melakukan kajian dengan judul "Kompilasi Hukum Islam dalam Perspektif Hukum Perundang-Undangan”. Hasil penelitian ini menunjukkan bahwa Instruksi Presiden RI Nomor 1 Tahun 1991 tentang Penyebarluasan Kompilasi Hukum Islam menjadi bermasalah jika dihadapkan dengan Undang-Undang Nomor 10 Tahun 2004 tetang Pembentukan Peraturan Perundangundangan. Instruksi presiden tidak termasuk dalam hierarki peraturan perundangundangan. Meskipun demikian, hakim di Pengadilan Agama tetap menggunakan Kompilasi Hukum Islam sebagai rujukan dalam memutus perkara karena dianggap sebagai fiqh khas Indonesia. ${ }^{11}$

Kemudian, kajian yang dilakukan oleh Yufi Wiyos Rini dengan judul. "Pandangan Politik Hukum Islam Terhadap KHI di Indonesia". Hasil kajian ini menunjukkan bahwa penyusunan Kompilasi Hukum Islam merupakan efek dari politik akomodatif pemerintah orde baru terhadap kepentingan umat Islam di Indonesia. ${ }^{12}$ Intan Cahyani melakukan kajian dengan judul "Pembaharuan Hukum dalam Kompilasi Hukum Islam”. Hasil penelitiannya menunjukkan bahwa lahirnya Kompilasi Hukum Islam merupakan wujud pembaharuan hukum Islam di Indonesia yang diamanatkan oleh konstitusi. Kompilasi Hukum Islam merupakan produk fiqh khas Indonesia yang dapat ditafsirkan sesuai dengan konteks. ${ }^{13}$ Riset yang dilakukan oleh Dadang Hermawan dan Sumardjo dengan judul "Kompilasi Hukum Islam Sebagai Hukum Materiil Pada Peradilan Agama". Hasil kajian ini menunjukkan bahwa Kompilasi Hukum Islam masih tetap digunakan sebagai sumber hukum di Pengadilan Agama, terlepas dari perdebatan tentang status Kompilasi Hukum Islam dalam sistem hukum nasional Indonesia. ${ }^{14}$ Berbagai kajian di atas belum membahas tentang penyerapan fiqh mazhab Syafi'i dalam penyusunan Berdasarkan persoalan ini, artikel ini bertujuan

\footnotetext{
9 Abdul Hadi, "Fiqih Mazhab Syafi'i Dalam Peraturan Perundang-Undangan Tentang Perkawinan Di Indonesia, Brunei, Dan Malaysia (1971-1991)" (phd, UIN Sunan Kalijaga, 2000), 222-24, http://digilib.uin-suka.ac.id/14394/.

10 Author: Nurjihad, "Pembaharuan Hukum Islam Di Indonesia Studi Kasus CLD Kompilasi Hukum Islam," Jurnal Hukum IUS QUIA IUSTUM 11, no. $27 \quad$ (2004): 116, https://doi.org/10.20885/iustum.vol11.iss27.art10.

11 Yulkarnain Harahap and Andy Omara, "Kompilasi Hukum Islam Dalam Perspektif Hukum PerundangUndangan," Mimbar Hukum 22, no. 3 (2010): 644, https://doi.org/10.22146/jmh.16245.

12 Yufi Wiyos Rini, "Pandangan Politik Hukum Islam Terhadap KHI Di Indonesia," ASAS 3, no. 1 (February 14, 2011): 38, http://ejournal.radenintan.ac.id/index.php/asas/article/view/1650.

13 Intan Cahyani, "Pembaharuan Hukum Dalam Kompilasi Hukum Islam," Al Daulah: Jurnal Hukum Pidana Dan Ketatanegaraan 5, no. 2 (December 14, 2016): 312, https://doi.org/10.24252/ad.v5i2.4850.

${ }^{14}$ Dadang Hermawan and Sumardjo Sumardjo, "Kompilasi Hukum Islam Sebagai Hukum Materiil Pada Peradilan Agama," YUDISIA : Jurnal Pemikiran Hukum Dan Hukum Islam 6, no. 1 (August 16, 2016): 44, https://doi.org/10.21043/yudisia.v6i1.1469.
} 
mendeskripsikan sejarah penyusunan Kompilasi Hukum Islam dan mengidentifikasi penyerapan mazhab Syafi'i pada Buku I Kompilasi Hukum Islam Tentang Perkawinan.

\section{Metode Penelitian}

Artikel ini berasal dari penelitian normatif, dimana sumber utamanya adalah literatur kepustakaan. Selanjutnya dalam pemaparan data, peneliti menggunakan metode deskriptif. Dalam penelitian ini, peneliti ingin menelusuri dan membuktikan bahwa adanya pengaruh madzhab Syafi'i dalam KHI serta membuktikan beberapa pasal dalam KHI yang memiliki kesamaan dengan faham mazhab Syafi'i. adapun sumber data yang peneliti gunakan dalam penelitian ini baik sumber data primer maupun skunder adalah sumber baik dari buku maupun jurnal yang membahan tentang madzhab dalam hukum Islam, Kompilasi Hukum Islam, serta beberapa kitab turats yang dijadikan acuan dalam pembahasan materi pada KHI, serta beberapa sumber yang memiliki keterkaitan pembahasan.

\section{Hasil dan Pembahasan}

\section{Sejarah Penyusunan Kompilasi Hukum Islam}

Kompilasi Hukum Islam muncul bukan dari ruang hampa. Kompilasi Hukum Islam lahir sebagai respons atas ketidakseragaman putusan hakim pengadilan agama. ${ }^{15}$ Sebagai respons atas persoalan ini, pemerintah membentuk tim pelaksana proyek penyusunan draf hukum materiil pengadilan agama melaui Surat Keputusan Bersama (SKB) Ketua Mahkamah Agung RI dan Menteri Agama RI No.07/KMA/1985 dan Nomor 25 Tahun 1985. Tim penyusunan draf hukum materiil pengadilan agama ini diketuai oleh Prof. Busthanul Arifin, S.H, Ketua Muda Urusan Peradilan Agama Mahkamah Agung RI. ${ }^{16}$

Kompilasi Hukum Islam disusun melalui beberapa tahapan, antara lain: pengumpulan data, wawancara, studi perbandingan, dan lokakarya. Draf Kompilasi Hukum Islam disusun berdasarkan kajian terhadap kitab-kitab fiqh mu'tabarah lintas mazhab. Kajian ini diserahkan kepada beberapa perguruan tinggi keagamaan Islam di Indonesia. Kajian meliputi 160 masalah pokok, baik perkawinan, kewarisan, wasiat, hibah, wakaf, dan sadaqah. Adapun perguruan tinggi yang terlibat dalam penyusunan draf Kompilasi Hukum Islam yaitu: IAIN Sunan Kalijaga Yogyakarta, IAIN Syarif Hidayatullah Jakarta, IAIN ar-Raniri Banda Aceh, IAIN Antasari Banjarmasin, IAIN Alaudin Ujung Pandang, IAIN Sunan Ampel Surabaya, dan IAIN Imam Bonjol Padang. Tim penyusun draf Kompilasi Hukum Islam melakukan wawancara dengan 181 ulama di wilayah Aceh, Medan, Padang, Palembang, Bandung, Surakarta, Surabaya, Banjarmasin, Ujung Pandang dan Mataram. Kemudian dilakukan kajian terhadap produk pengadilan agama. Dan melakukan kajian perbendingan hukum keluarga dari Maroko, Mesir dan Turki.

Data hasil kajian kitab fiqh, hasil penelitian, wawancara, studi banding, dan yurisprudensi kemudian dirumuskan oleh tim yang lebih besar. Rumusan draf hukum materiil ini kemudian dibahas lagi oleh tim inti, sebelum masuk pada forum lokakarya. Pembentukan Kompilasi Hukum Islam berlangsung selama dua hari, yaitu tanggal 2-6

\footnotetext{
15 Andi Herawati, "Kompilasi Hukum Islam (Khi) Sebagai Hasil Ijtihad Ulama Indonesia," HUNAFA: Jurnal Studia Islamika 8, no. 2 (December 17, 2011): 323, https://doi.org/10.24239/jsi.v8i2.367.321-340.

16 Keputusan Bersama Ketua Mahkamah Agung Dan Menteri Agama Republik Indonesia Nomor : 07/KMA/1985 dan Nomor : 25 Tahun 1985 Tentang Penunjukan Pelaksana Proyek Pembangunan Hukum Islam melalui Yurisprudensi
} 
Februari tahun 1988 di hotel Kartika Candra Jakarta dan diikuti 124 peserta dari seluruh Indonesia. Dengan lahirnya Kompilasi Hukum Islam diharapkan dapat terwujud: 1) munculnya kesatuan landasan hukum (unifed legal frame work) dan keseragaman pandangan hukum (unifed legal opinion). Tujuannya memperkecil putusan yang disparitas dalam kasus yang sama; 2) membina kepastian penegakan hukum bagi umat Islam di Indonesia; 3) memberi perlakuan yang sama dalam kasus yang sama (equal treatment in similar cases). Hakim pengadilan agama memiliki standar yang baku dalam memutus perkara. ${ }^{17}$.

Kompilasi Hukum Islam disusun berdasarkan kajian atas 38 kitab fiqh klasik, antara lain: al-Bâjûriy, Fath al-Mu'în, Syarqâwi 'alâ al-Tahrîr, Mughnî al-Muhtâj, Nihâyat al-Muhtâj, al-Syarqâwî, I'ânat al-Tâlibîn, Tuhfah, Targîb al-Musytâq, Bulghah al-Sâlik, Syamsurî fî̀ al-Farâ'id, al-Mudâwanah, Qalyûbî/Mahallî, Fath al-Wahab dengan Syarh-nya, al-Umm, Bughyat alMustarsyidîn, Bidâyat al-.Mujtahid, 'Aqîdah wa al-Syarî'ah, al-Muhalla, al-Wajîz, Fath al-Qadîr, al-Fiqh 'alâ Madhâhib al-Arba'ah, Fiqh al-Sunnah, Kasyf al-Qinâ', Majmû'ah al-Fatâwâ ibn Taymiyah, Qawânîn alSyar'iyyah Lî al-Sayyid Utsmân bin Yahya, al-Mughnî, al-Hidâyah Syarh al-Bidâyah Taymiyyah al-Mubtadi, Qawânîn al-Syar'iyyah Lî al-Sayyid Sudâqah Dahlân, Nawâb al-Jalîl, Syarh ibn 'Abidîn, al-Muwattâ', Hâsyiyah. ${ }^{18}$

Ada dominasi kitab-kitab fiqh mazhab Syafi'i dalam penyusunan Kompilasi Hukum Islam tidak bisa dihindarkan. Kondisi ini tidak a historis, melainkan berkaitan dengan proses penyebaran Islam di wilayah nusantara. Islam disebarluaskan oleh orangorang Arab yang bermazhab Syafi'i pada abad I H/VII M. Sedangkan kitab-kitab fiqh mazhab lain yang dijadikan sumber penyusunan seperti kitab al-Hidâyah dan Fath alQadîr dari madzhab Hanafî, kitab al-Muwatta' dan al-Mudâwanah dari mazhab Mâlikî dan Hanbalî yaitu kitab al-Mughnî dan al-Fatâwâ alHindiyah. Kemudian madzhab Dhahirî yaitu al-Muhalla. Bahkan kitab Fath al-Qadîr oleh al-Syawkanî berasal dari mazhab Syi'ah. Selain itu, ada beberapa kitab fiqh perbandingan madzhab seperti alFiqh 'Alâ Madhâhib al-Arba'ah dan tanpa madzhab I'lâm al-Muqi'în. Kondisi ini menjukkan bahwa untuk menjawab berbagai persoalan umat Islam di Indonesia tidak cukup menggunakan satu pandangan mazhab saja. Dengan kata lain, materi Kompilasi Hukum Islam tidak terikat oleh satu mazhab tertentu. Pertentangan antar mazhab dapat dihindari dan diarahkan kepada perpaduan untuk menciptakan kemaslahatan. Kondisi ini menunjukkan bahwa para penyusun Kompilasi Hukum Islam berfikir terbuka dan tidak terikat oleh satu mazhab saja. ${ }^{19}$

\section{Penyerapan Fiqh Mazhab Syafi’i dalam Kompilasi Hukum Islam}

Sebagaimana telah dibahas pada bagian sebelumnya, beberapa pasal Kompilasi Hukum Islam yang berkaitan dengan syarat dan rukun perkawinan disinyalir diserap dari pandangan fiqh mazhab Syafi'i. Pertama, aturan tentang peminangan sebagaimana diatur dalam Pasal 11-13 Kompilasi Hukum Islam. Peminangan merupakan satu perbuatan yang mengarah kepada terjadinya hubungan perjodohan. Peminangan dapat dilakukan oleh orang yang berkeinginan menikah atau melalui perantara. Peminangan dapat dilakukan terhadap seorang`wanita yang masih perawan atau terhadap janda yang

\footnotetext{
${ }^{17}$ Rahman, "Kompilasi Hukum Islam," 72.

18 Moh Asy'ari, "Kompilasi Hukum Islam Sebagai Fiqh Lintas Madzhab Di Indonesia," AL-IHKAM: Jurnal Hukum \& Pranata Sosial 7, no. 2 (October 14, 2014): 240, https://doi.org/10.19105/alihkam.v7i2.326.

19 Asy'ari, 243.
} 
telah habis masa iddahnya. Wanita yang ditalak suami yang masih berada dalam masa iddah raj'iah, haram dan dilarang untuk dipinang. Seseorang dilarang meminang seorang wanita yang sedang dipinang pria lain, selama pinangan pria tersebut belum putus atau belum ada penolakan dan pihak wanita. Kompilasi Hukum Islam menegaskan bahwa terjadinya peminangan belum menimbulkan akibat hukum, sehingga para pihak bebas untuk memutuskan hubungan. Meskipun demikian, pemutusan hubungan ini tetap memperhatikan sikap saling menghargai dan menciptakan kerukunan di kemudian hari. ${ }^{20}$

Berkaitan dengan peminangan, Sayyid Sabiq dalam kitab Fiqh al-Sunnah, mengatakan:

$$
\begin{aligned}
& \text { والخطبة من مقدّمات الزواج. و قد شرّعها الله قبل الإرتباط بعقد الزوجية ليتعرّف كلّ من الزوجين } \\
& \text { صاحبه. و من تباح خطبتها : أولا, لا تباح خطبة امرأة إلاّ إذا توافر فيها شرطان : أن تكون خالية } \\
& \text { من الموانع الشرعية التى تمنع زواجه منها في الحال. ثانيا, ألاّ يسبقه غيره إليها بخطبة شرعية. } \\
& \text { تحرم خطبة المعتدة سواء اكانت عدتها عدة وفاة ام عدة طلاق, اكان الطلاق طلاقا رجعيا ام } \\
& \text { بائنا. فإن كانت معتدة من طلاق رجعي حرمت خطبتها لانها لم تخرج عن عصمة زوجها. و له } \\
& \text { مراجعتها في اي وقت شاء. و إن كانت من طلاق بائن حرمت خطبتها بطريق التصريح إذ حق } \\
& \text { الزوج لا يزال متعلقا بها. و له حق اعادتها بعقد جديد }
\end{aligned}
$$

Menurut Sayyid Sabiq - salah satu pengikut madzhab Syafi'i bahwa peminangan atau dalam bahasa arab dikenal dengan khitbah merupakan permulaan dari pernikahan. Allah telah mensyari'atkan khitbah sebelum terikat dalam suatu akad pernikahan agar antara kedua belah pihak baik pihak laki-laki atau pihak perempuan bisa lebih saling mengenal. Lebih lanjut beliau menegaskan bahwa perempuan yang boleh dipinang memiliki dua syarat. Pertama, perempuan tersebut bebas dari halangan-halangan secara syar'iyah yang mencegah terjadinya pernikahan dan, kedua perempuan tersebut tidak dalam pinangan orang lain. ${ }^{21}$ Syaikh Syamsuddin Muhammad Bin Al-Khatib AlSyirbani Al-Syafi'i dalam kitab Mughni al-Muhtāj mengatakan:

$$
\begin{aligned}
& \text { تحلّ خطبة خلية عن نكاح و عدّة, لا تصريح لمعتدّة, ولا تعريض لرجعية. و تحرم خطبة على } \\
& \text { خطبة من صرّح بإجابته إلاّ بإذنه. }
\end{aligned}
$$

Syaikh Syamsuddin Muhammad memberi penjelasan tentang pinangan ( $A l$ Khitbah) bahwa melakukan pinangan itu diperbolehkan terhadap wanita yang tidak terikat dalam pernikahan dan perempuan yang tidak sedang menjalani masa iddah. Pinangan juga tidak boleh dilakukan terhadap wanita yang telah dipinang oleh orang lain kecuali orang yang meminang wanita tersebut memberikan izin. ${ }^{22} \mathrm{Hal}$ ini berdasarkan sebuah hadits:

\footnotetext{
20 Fathur Rahman, "Hukum Adat Peminangan Dan Perkawinan Di Komunitas Muslim Minoritas Jimbaran Bali," Al-Mazahib (JURNAL PEMIKIRAN HUKUM) 2, no. 1 (June 1, 2014): 141, http://ejournal.uin-suka.ac.id/syariah/almazahib/article/view/1401.

${ }^{21}$ Sayyid Sabiq, Fiqh Al-Sunnah (Cairo: Al-Fath Li Al-I'laam Al-Araby, n.d.), 16.

22 Syamsuddin Muhammad Bin Al-Khatib Al-Syirbani, Mughni Al-Muhtāj, vol. 3 (Lebanon: Daar AlMa'rifat, n.d.), 183.
} 


$$
\text { لايخطب الرجل على خطبة أخيه حتّى يترك الخاطب قبله أو يأذن له الخاطب. (رواه الشيخان) }
$$

Artinya: Tidaklah seorang laki-laki meminang diatas pinangan saudaranya sehingga saudaranya teersebut meninggalkan pinangannya atau memberikan izin padanya. (Diriwayatkan oleh Imam Bukhari dan Imam Muslim).

Kemudian dalam Pasal 14 Kompilasi Hukum Islam dikatakan bahwa untuk melaksanakan perkawinan harus ada : calon suami, calon istri, wali nikah, dua orang saksi dan ijab dan kabul. Dalam kitab Fath al-Wahhab, Syaikh Zakariya bin Muhammad mengatakan:

$$
\text { الشافعي: أركان النكاح خمسة : زوج وزوجة وولي وشاهدان وصيغة }
$$

Kalangan Syafi'iyah menggunakan istilah rukun nikah yang terdiri dari mempelai laki-laki, mempelai perempuan, wali, dua orang saksi, dan shigat. ${ }^{23}$ Berkaitan dengan wali Pasal 19 Kompilasi Hukum Islam menyatakan bahwa wali nikah dalam perkawinan merupakan rukun yang harus dipenuhi bagi calon mempelai wanita yang bertindak untuk menikahkannya. Dalam Fiqh 'ala Mazhabib al-Arba'ah dinyatakan bahwa:

$$
\begin{aligned}
& \text { إتفق المالكية, والشافعية, و الحنابلة على ضرورة وجود الولى في النكاح. فكل نكاح يقع بدون } \\
& \text { الولى أو من ينوب منابه يقع باطلا, فليس للمرأة أن تباشر عقد زواجها بحال من الأحوال كانت } \\
& \text { كبيرة أو صغيرة عاقلة أو مجنونة إلا أنها كانت ثيبة لا يصلح زواجها بدون إذنها و رضايسا. } \\
& \text { الشافعي: فأي امرأة نكحت بغير إذن ولييها فلا نكاح لها. }
\end{aligned}
$$

Pandangan ini mengatakan bahwa setiap pernikahan seorang wanita yang terjadi tanpa adanya wali atau orang yang berhak menggantikannya, maka pernikahan tersebut batal atau dengan kata lain tidak sah sehingga wanita tersebut tidak dapat menikahkan dirinya sendiri tanpa adanya seorang wali. Maka menurut pandangan madzhab Syafi' i, wanita yang menikah tanpa idzin atau ridha walinya maka tidak ada nikah bagi wanita tersebut. ${ }^{24}$

Pasal 21 yang membahas tentang wali, memberikan pemahaman tentang wali dalam ayat-ayat sebagai berikut: Pertama, wali nasab terdiri dari empat kelompok dalam urutan kedudukan, kelompok yang satu didahulukan dan kelompok yang lain sesuai erat tidaknya susunan kekerabatan dengan calon mempelai wanita. Kelompok pertama yaitu kerabat laki-laki garis lurus keatas yakni ayah, kakek dari pihak ayah dan seterusnya. Kelompok kedua kerabat saudara laki-laki kandung atau saudara laki-laki seayah, dan keturunan laki-laki mereka. Kelompok ketiga yaitu kerabat paman, yakni saudara laki-laki kandung ayah, saudara seayah dan keturunan laki-laki mereka. Kelompok keempat yaitu saudara laki-laki kandung kakek, saudara laki-laki seayah dan keturunan laki-laki mereka. Kedua, Apabila dalam satu kelompok wali nikah terdapat

\footnotetext{
${ }^{23}$ Zakariya bin Muhammad al-Anshary, Fath Al-Wahhab, vol. 2 (Beirut: Dar al-Ma'rifah, n.d.), 37.

24 Abdur Rahman al-Jaziri, Al-Fiqh Ala Madzāhib Al-Arba'ah, vol. 4 (Libanon: Daar Al-Kutub AlIlmiyah, n.d.), 30 .
} 
beberapa orang yang sama-sama berhak menjadi wali, maka yang paling berhak menjadi wali ialah yang lebih dekat derajat kekerabatannya dengan calon mempelai wanita. Ketiga, Apabila dalam satu kelompok sama derajat kekerabatannya, maka yang paling berhak menjadi wali nikah ialah kerabat kandung dari kerabat yang hanya seayah. Keempat Apabila dalam satu kelompok, derajat kekerabatannya sama yakni sama-sama derajat kandung atau sama-sama derajat kerabat seayah, maka mereka samasama berhak menjadi wali nikah, dengan mengutamakan yang lebih tua dan memenuhi syarat-syarat wali.

$$
\begin{aligned}
& \text { الشافعي: فأي امرأة نكحت بغير إذن ولييها فلا نكاح لها. } \\
& \text { قال الشافعي رحمه الله تعالى : ولا ولاية لأحد مع أب. فإذا مات فالجدّ أبو الأب. فإذا مات } \\
& \text { فالجد أبو الجد لأنّ كلهم أب و كذلك الأباء. و ذلك أنّ المزوجة من الأباء و ليست من } \\
& \text { الإخوة. و الولاية غير المواريث. ولا ولاية لأحد من الأجداد دونه أب أقرب إلى المزوجة منه. فإن إن }
\end{aligned}
$$

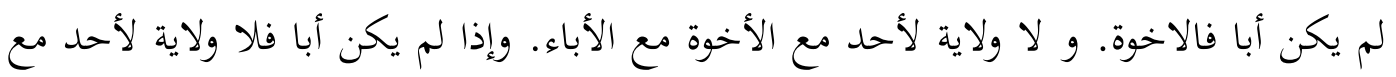

$$
\begin{aligned}
& \text { الإخوة, و إذا اجتمع الإخوة فبنوالأب والأمّ اولى من بنى الأب. فإذا لم يكن بنو أمّ و أب فبنو } \\
& \text { الأب أولى من غيرهم. ولا ولاية لبنى الأمّ بالأم و لا لجدّ أبي أمّ إن لم يكن عصبة, لأن الولاية } \\
& \text { للعصبة. فإن كانوا بنى عم و لا أقرب منهم كانت لهم الولاية بأنهم عصبة, و إن كان معهم مثلهم }
\end{aligned}
$$

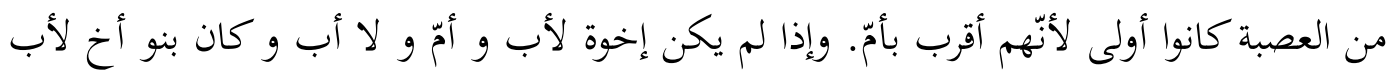

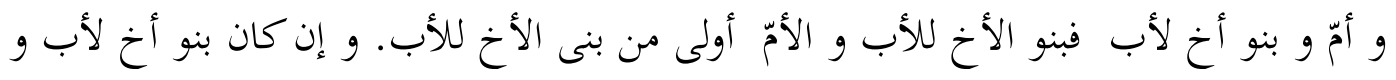

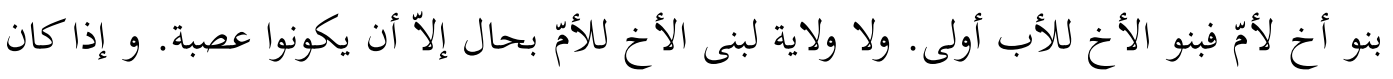

$$
\begin{aligned}
& \text { الولي حاضرا فامتنع من التزويج فلا يزوّجها الولى الذي يليه في القرابة و لا يزوّجها إلاّ السلطان } \\
& \text { الذي يجوز حكمه. }
\end{aligned}
$$

Dalam kitab Al-Umm, tentang wali Imam Syafi'i mengatakanbahwa seorang wanita yang menikah tanpa wali, maka ia tidak dapat melangsungkan pernikahan tersebut. Dalam kitab Al-Umm juga dijelaskan bahwa urutan wali dimulai dari bapak. Apabila tidak ada seorang bapak, maka yang menggantikannya ada kakek (bapaknya bapak) terus keatas melalui jalur bapak. Apabila wali dari bapak keatas tidak ada, maka yang berhak menjadi wali adalah saudara laki-laki sebapak seibu. Namun jika tidak ada wali dari saudara laki-laki sebapak seibu, maka kemudian yang menjadi wali adalah saudara laki-laki sebapak dan terus kebawah. ${ }^{25}$

Proses pelaksanaan pernikahan juga menyerap ketentuan fiqh mazhab Syafi'i. Dalam ketentuan Pasal 27 Kompilasi Hukum Islam dinyatakan bahwa ijab dan kabul antara wali dan calon mempelai pria harus jelas beruntun dan tidak berselang waktu. Dalam kitab Mugni Al-Muhtaj, Syaikh Syamsuddin menyadur pendapat Imam Syafi'i yang menyatakan :

\footnotetext{
${ }^{25}$ Muhammad Bin Idris Al-Syafi'i, Al-Umm (Beirut: Dar Al-Wafa', n.d.), 35-38.
} 


$$
\begin{aligned}
& \text { الإمام الشافعي يقول إنّما يصح النكاح بإيجاب و قبول. و لا يصح إلاّ بلفظ التزويج أو }
\end{aligned}
$$

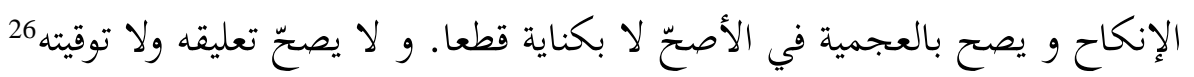

Bahwa sahnya suatu pernikahan itu dengan mengucapkan ijab dan Kabul. Suatu akad dikatakan sah apabila dalam kalimat akad tersebut ada kata Tazwij (kawin) dan Inkah asalkan ucapan tersebut dapat dipahami dan jelas dan juga tidak berselang waktu. Imam Syafi'i juga memberikan penjelasan bahwa akad nikah tidak sah apabila disertai dengan ta'liq (menggantungkan) seperti contoh, jika matahari ini terbenam, maka akan aku nikahkan engkau dengan putriku. Akad nikah juga tidak sah apabila mengandung unsur tauqit (pembatasan waktu) seperti contoh, aku nikahkan engkau dengan putriku selama satu bulan

Berkaitan dengan Mahar ketentuan Pasal 33 menyatakan bahwa penyerahan mahar dilakukan dengan tunai. Apabila calon mempelai wanita menyetujui, penyerahan mahar boleh ditangguhkan baik untuk seluruhnya atau sebagian. Mahar yang belum ditunaikan penyerahannya menjadi hutang calon mempelai pria. Dalam ketentuan fiqh dinyatakan bahwa:

$$
\begin{aligned}
& \text { الشافعية: إذا كان الصداق مؤجلا فليس لها أن تمنع نفسها سواء حل الأجل قبل تسليم نفسها } \\
& \text { أو لا, لأنها متى رضيت بالتأجيل فقد وجب عليها أن تسلم نفسها فورا. }
\end{aligned}
$$

Pendapat Syafi'i diatas, secara implicit tidak mejelaskan tentang penyerahan mahar secara tunai, namaun jika dipahami dari teks diatas secara eksplisit bahwa mahar dapat diserahkan secara mu'ajjal (bertempo) dengan sepengetahuan dan persetujuan istri. Beliau menambahkan, jika memang istri memperkenankan suami untuk membayar mahar secara bertempo maka isti wajib menyerahkan diri sepenuhnya pada suami.

\section{Kesimpulan}

Berdasarkan pembahasan di atas dapat diambil kesimpulan bahwa Kompilasi Hukum Islam merupakan hasil ijtihad para pakar hukum Islam di Indonesia. Pengaruh mazhab Syafi'i lebih dominan dalam penyusunan Kompilasi Hukum Islam. Meskipun demikian, para perumus Kompilasi Hukum Islam menggunakan pendapat mazhab lain. Adopsi pemikiran mazhab Syafi'i dilatarbelakangi oleh adanya kebutuhan umat muslim Indonesia. Keputusan para ulama ini mempertimbangkan kemaslahatan bagi masyarakat muslim Indonesia. Dengan kata lain, Kompilasi Hukum Islam (KHI) hadir sebagai hukum Islam berwawasan Indonesia karena dalam penyusunannya sangat memperhatikan kondisi kebutuhan hukum umat Islam Indonesia. Keberadaan Kompilasi Hukum Islam (KHI) bukan sekedar pengadopsi, penghimpun atau pengumpul ketentuan-ketentuan fikih yang hidup dan berkembang dalam msyarakat muslim, namun merupakan bentuk tasyri' islamiy yang memuat hal-hal baru yang belum ada atau belum ditegaskan dalam kitab-kitab fikih terdahulu.

\footnotetext{
${ }^{26}$ Al-Syirbani, Mughni Al-Muhtāj, 3:188-92.
} 


\section{Daftar Pustaka}

Al-Syafi' i, Muhammad Bin Idris. Al-Umm. Beirut: Dar Al-Wafa', n.d.

Al-Syirbani, Syamsuddin Muhammad Bin Al-Khatib. Mughni Al-Muhtāj. Vol. 3. Lebanon: Daar Al-Ma'rifat, n.d.

Anshary, Zakariya bin Muhammad al-. Fath Al-Wahhab. Vol. 2. Beirut: Dar alMa'rifah, n.d.

Asy'ari, Moh. "Kompilasi Hukum Islam Sebagai Fiqh Lintas Madzhab Di Indonesia." AL-IHKAM: Jurnal Hukum \& Pranata Sosial 7, no. 2 (October 14, 2014): 23446. https://doi.org/10.19105/al-ihkam.v7i2.326.

Cahyani, Intan. "Pembaharuan Hukum Dalam Kompilasi Hukum Islam." Al Daulah: Jurnal Hukum Pidana Dan Ketatanegaraan 5, no. 2 (December 14, 2016): 30113. https://doi.org/10.24252/ad.v5i2.4850.

Hadi, Abdul. "Fiqih Mazhab Syafi'i Dalam Peraturan Perundang-Undangan Tentang Perkawinan Di Indonesia, Brunei, Dan Malaysia (1971-1991).” Phd, UIN Sunan Kalijaga, 2000. http://digilib.uin-suka.ac.id/14394/.

Harahap, Yulkarnain, and Andy Omara. "Kompilasi Hukum Islam Dalam Perspektif Hukum Perundang-Undangan." Mimbar Hukum 22, no. 3 (2010): 625-44. https://doi.org/10.22146/jmh.16245.

Herawati, Andi. "Kompilasi Hukum Islam (Khi) Sebagai Hasil Ijtihad Ulama Indonesia." HUNAFA: Jurnal Studia Islamika 8, no. 2 (December 17, 2011): 321-40. https://doi.org/10.24239/jsi.v8i2.367.321-340.

Hermawan, Dadang, and Sumardjo Sumardjo. "Kompilasi Hukum Islam Sebagai Hukum Materiil Pada Peradilan Agama." YUDISIA : Jurnal Pemikiran Hukum Dan Hukum Islam 6, no. 1 (August 16, 2016): 24-46. https://doi.org/10.21043/yudisia.v6i1.1469.

Jaziri, Abdur Rahman al-. Al-Fiqh Ala Madzāhib Al-Arba'ah. Vol. 4. Libanon: Daar AlKutub Al-Ilmiyah, n.d.

Koto, Alaidin. Sejarah Peradilan Islam. Jakarta: RajaGrafindo Persada, 2011.

Keputusan Bersama Ketua Mahkamah Agung Dan Menteri Agama Republik Indonesia Nomor : 07/KMA/1985 dan Nomor : 25 Tahun 1985 Tentang Penunjukan Pelaksana Proyek Pembangunan Hukum Islam melalui Yurisprudensi

Lubab, Nafiul, and Novita Pancaningrum. "Mazhab: Keterkungkungan Intelektual Atau Kerangka Metodologis (Dinamika Hukum Islam)." YUDISIA : Jurnal Pemikiran Hukum Dan Hukum Islam 6, no. 2 (December 1, 2015): 394-413. https://doi.org/10.21043/yudisia.v6i2.1462.

Manan, Abdul. Penerapan Hukum Acara Perdata Di Lingkungan Peradilan Agama. Jakarta: Kencana, 2010.

Mujahidin, Ahmad. Pembaruan Hukum Acara Perdata Peradilan Agama Dan Mahkamah Syari'ah Di Indonesia. Jakarta: IKAHI, 2008.

Nurjihad, Author: "Pembaharuan Hukum Islam Di Indonesia Studi Kasus CLD Kompilasi Hukum Islam.” Jurnal Hukum IUS QUIA IUSTUM 11, no. 27 (2004): 106-17. https://doi.org/10.20885/iustum.vol11.iss27.art10.

Rahman, Fathur. "Hukum Adat Peminangan Dan Perkawinan Di Komunitas Muslim Minoritas Jimbaran Bali.” Al-Mazahib (JURNAL PEMIKIRAN HUKUM) 2, no. $1 \quad$ (June 1 2014). http://ejournal.uinsuka.ac.id/syariah/almazahib/article/view/1401.

Rahman, Muhammad Gazali. "Kompilasi Hukum Islam Sebagai Hukum Terapan Bagi Hakim Pengadilan Agama." Tahkim 11, no. 2 (2015). 
Rini, Yufi Wiyos. "Pandangan Politik Hukum Islam Terhadap KHI Di Indonesia." ASAS 3, no. 1 (February 14, 2011). http://ejournal.radenintan.ac.id/index.php/asas/article/view/1650.

Sabiq, Sayyid. Fiqh Al-Sunnah. Cairo: Al-Fath Li Al-I'laam Al-Araby, n.d. 